\title{
Decolonising the Photography of Palestine: Searching for a Method in a Plate of Hummus
}

\author{
Stephen Sheehi
}

Kafr Qasim ${ }^{1}$

No commemoration, no flowers, no remembrance

No poetic verse humanizing the murdered. Not one line.

No shred from the shirt soaked in blood

Remains from our innocent brothers.

No one thing except shame.

Their ghosts continue to circle

Unearthing the graves in the ruins of Kafr Qasim.

SAMIH QASIM

I begin this chapter with Samih Qasim's poem to Kafr Qasim, a village where the Israeli military massacred 48 Palestinians (23 of whom were children). In teaching us 'how to read a massacre', Rana Barakat forces us to remember that the structural and intentional violence of settler colonialism, in this case Zionism, must never decentre those narratives, presence and material realities of the indigenous population - the very selves targeted for elimination. ${ }^{2}$ Let us keep this axiom, then, in mind when we consider militant methodologies to re-centre, witness and validate indigenous presence in settler-colonial photography. To start this exploration, I would like to start this inquiry then

1 Samih Qassim, "Kafr Qassim" (poem in Arabic) in Abdelwahab Elmessiri, The Palestinian Wedding: A Bilingual Anthology of Contemporary Palestinian Poetry (Washington, D.C.: Three Continents Press, 1982); my translation. Kafr Qasim was a village where Israeli Border Police, massacred 48 Palestinian-Israeli civilians (over half children under 17 and a pregnant women) on the eve of Israel's invasion of the Sinai in 1956. All victims were Israeli-Palestinian citizens.

2 Rana Barakat, "How to Read a Massacre in Palestine: Indigenous History as a Methodology of Liberation" (unpublished draft copy, 2019). 


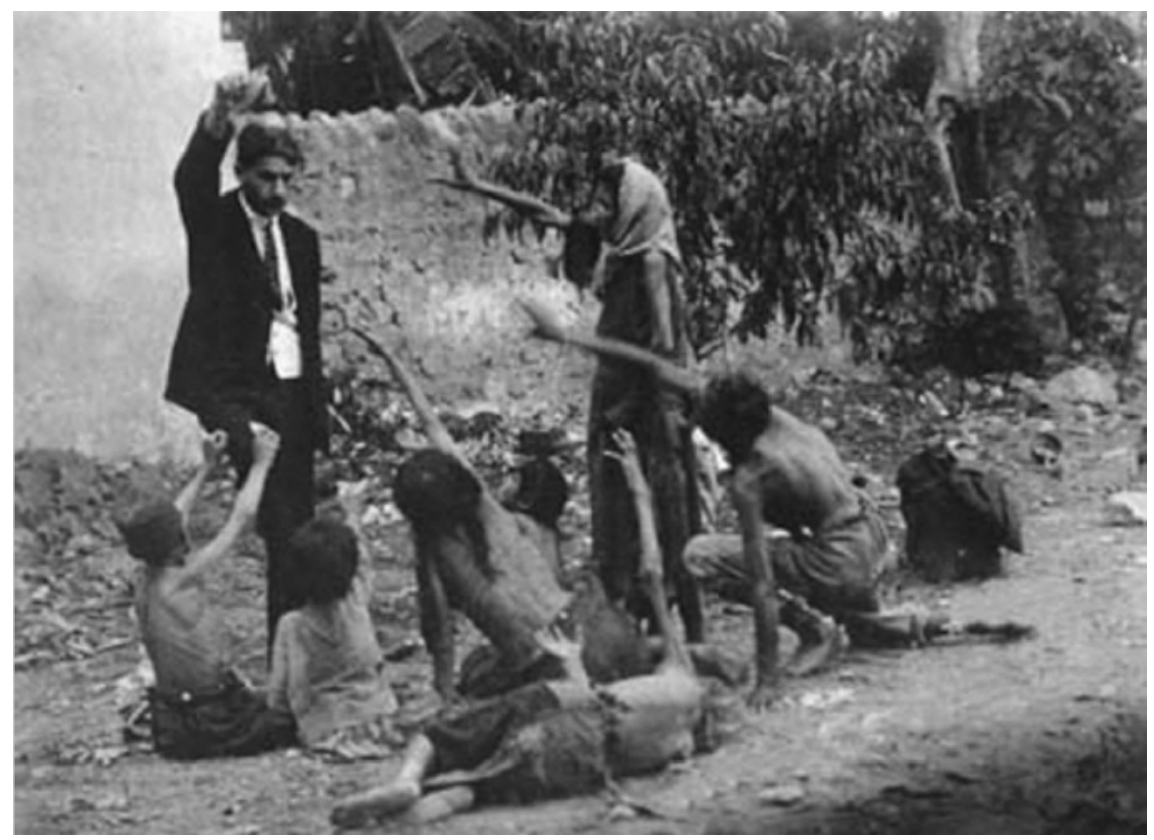

FIG URE 10.1 'Turkish Official Teases Starving Armenian Children', 1915. (Featured in Donald Bloxham)

with the familiar, to some, yet scandalous photograph. Indeed, a photograph from the time of the British Mandate of Palestine. In some ways, it is not unrelated. It is likely that those familiar with the ongoing saga to recognise the Armenian Genocide know this now infamous image, putatively of a 'Turkish Official Taunting Armenians with Bread', also known as 'Famished Armenian Children'. The image is found in Armin Wegnar's well-known photographs documenting the genocide, many of which he and fellow German officers took while deployed in Ottoman Syria during World War I. Subsequently, the photograph was the cover-image of Donald Bloxham's 2010 Great Game of Genocide. ${ }^{3}$ The image is, however, not of starving and taunted Armenians but it is, in fact, a staged French image used for funding raising to alleviate the Great Famine in Lebanon during the same period. Rather than being identified as a scholarly error or a misidentified image, the photograph was deemed a 'forgery' by

3 Donald Bloxham, The Great Game of Genocide: Imperialism, Nationalism, and the Destruction of the Ottoman Armenians (Oxford: Oxford University Press, 2005). 
Genocide-deniers. As such, it was used as one more piece of evidence that Armenians continue to be the liars and forgers, truly the 'seditious millet'. ${ }^{4}$

This controversy returns us to the perennial, if not banal, questions of photography's documentary 'validity', its constructedness, and its artifice in contrast to its 'truth-value'. Lacan reminds, however, that:

Méconnaissance is not ignorance. [It] represents a certain organization of affirmations and negations, to which the subject is attached. Hence it cannot be conceived without correlate knowledge (connaissance)... [Therefore], behind one's misrecognition, there must surely be a kind of knowledge of what there is to misrecognize. ${ }^{5}$

But these questions seem to me to be a deflection from another issue that underscores the compulsion to forgery or the méconnaissance of the weak. This photographic méconnaissance of the colonised, of the genocided, happens when the photograph represents so fully and cogently one's own selfhood and material reality that are otherwise been denied by hegemonic power and its ability to control knowledge and image production.

Therefore, the question of forgery (locked in orbit with méconnaissance) raises not only the question of validity or truth of the photograph. More importantly, forgery raises the question of right to truth, the right to the social relations and material realities photography represents: the right to the surplus truth-value of the photograph (as value accumulated through the political economy of representation and image-circulation).

Let us move to an equally controversial image. An image that is 'real' but contested, indeed, legally contested. On 3oth September 2000, two days after Ariel Sharon's provocative visit to the Harām al-Shariff, Muhammad Durrah, a 12-year-old boy, was shot dead in the arms of his father in Gaza by the Israeli army. He was shot in front of Talal Abu Rahma's camera, filming video footage for France 2 news. Captured in less than minute of video, Durrah's death was reduced to a series of photographic stills that circulated throughout Palestine, the Arab world and the globe. The image has become iconic. Despite the power of this image, or perhaps because of the power of this image, Israel retracted its initial admission of guilt to later deny the validity of the claims that Durrah

4 Vahakn Dadrian, "The Armenian Question and the Wartime Fate of the Armenians as Documented by the Officials of the Ottoman Empire's World War I Allies: Germany and Austria-Hungary," International Journal of Middle East Studies vol. 34, no. 1 (2002): 59-85.

5 Jacques Lacan, The Seminar Book I: Freud's Papers on Technique 1953-54, trans. John Forrester (New York: Norton, 1988), 167 (my translation tweak). 


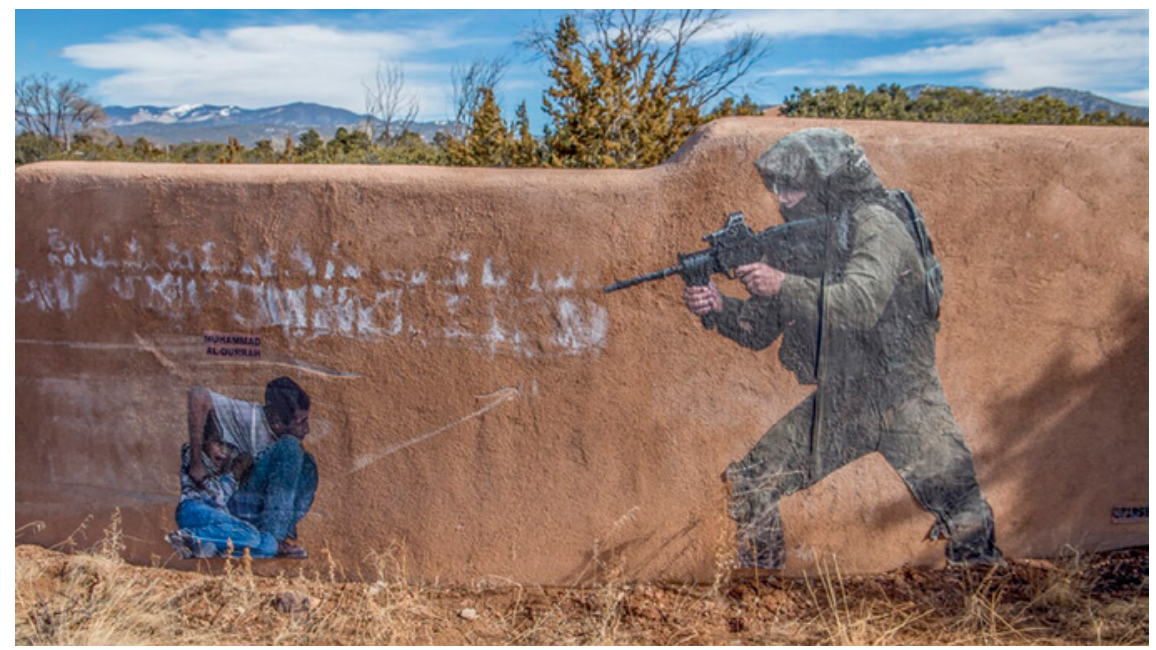

FIgURE 10.2 Mohammed al-Durrah Mural. Santa Fe, NM, by artist Remy. IMAGE COURTESY OF ALEX DE VOSE

was killed by Israeli forces and contest the validity of the images. Charles Enderline, France 2's Israel Bureau chief, became embroiled in several legal battles around defamation of his character and the validity of his reporting of the incident.

Rather than serve as evidence for the violence that afflicts Palestinian civilians under occupation, the iconic image emerged as a point of contention, transformed in the international arena (and French courts) from an indictment of Israeli occupation to proof, or at least innuendo, of the deceitfulness of Palestinians. The alchemy of politics and power converted the photographic evidence of a murdered 12-year-old into a document that allegedly demonstrates artifice, deflection, manipulation and the sedition of the victim.

Melanie Phillips, a British commentator, has made a career off the 'controversy' that she played a large part in creating. ${ }^{6}$ But even more so, Phillips mobilised the virility and ubiquity of the visual evidence of the Israeli murder of Durrah to allege that the image itself resulted in the true loss of many lives (meaning Jewish and Israeli-Jewish lives). Phillips' activism around the death image of Durrah makes us think of who has the right to determine the veracity of an image, the force and currency of an image. Nick Mirzeoff speaks of 'right

6 Melanie Phillips, "Faking a Killing," Standpoint, June 27, 2008, found at https://standpoint mag.co.uk/faking-a-killing-july/?page $=0 \% 2 \mathrm{Co} \% 2 \mathrm{Co} \% 2 \mathrm{Co} \% 2 \mathrm{Co} \% 2 \mathrm{Co} \% 2 \mathrm{Co} \% 2 \mathrm{Co} \% 2 \mathrm{Co} \% 2$ $\mathrm{Co} \% 2 \mathrm{C} 2$. 
to look' as a constituent tension within the history of modern visuality that comes into being through the claims and counterclaims between the coloniser and colonised. ${ }^{7}$

I recalibrate Nick Mirzeoff's formulation 'right to look' to a formulation of the right to the 'surplus truth value' of photography. Let me be clear that I am not talking about the right to representation. Indeed, a current trend in photography studies is to move away from focusing exclusively on the photographs of Orientalist photographers to try to locate indigenous histories of photography and/or the hidden role of indigenous assistants (often women as readily as men) of Western expatriate photographers. I am not referring to local histories and personal accounts, often very important accounts in themselves, being told through autogenerated photographs. ${ }^{8}$

Let us understand that the practice of photography is an extractive process, especially when it is in the hands of the coloniser, the imperialist or the Zionist settler. Even if the photographer seeks to 'humanise' the indigenous subject, this gesture of magnanimity originates from an economy of images, representations, commodity exchange, subjectivities, epistemology. Therefore, such knowledge-production is structured to extract all forms of wealth and value (whether subjective, aesthetic, historical or material) from the colonised and transfer it to the coloniser along with its title (that it creates from this process). Therefore, I am stating that the photograph-forged through this colonial subjective, political and epistemological economy must understood as property. This does not only include the photographic object, the processes and labour around its production and dissemination. The photographic index itself is property, whose surplus-value the coloniser has usurped as part of the colonising enterprise. When this right to the surplus truth-value of photography is managed in such a way that it excludes, when it is used to further disavowal, and when it perpetuates the interests of power, violence and denial, forgery rightfully becomes 'a weapon of the weak', who themselves seize the right to all surplus-value extracted from colonial people and lands in an on-going struggle with coloniality.

I am not arguing to assert the right to claim a forgery or a falsehood as real. Rather, I am arguing the right to claim the representation of violence is real and

7 Nicholas Mirzoeff, The Right to Look: A Counterhistory of Visuality (Durham, NC: Duke University Press, 2011).

8 See, for example, Naseeb Shaheen, A Pictorial History of Ramallah (Beirut: Arab Institute for Research and Publishing, 1992); Walid Khalidi, Before Their Diaspora: A Photographic History of the Palestinians 1876-1948 (Washington D.C.: Institute for Palestine Studies, 1984); and Badr el-Hage, Shweir and Its Hills: A Photographic Record, trans. Sabah Ghandour (Beirut: Kutub, 2013). 
that social conditions that make that representation are true. I am arguing the right to claim the photograph because it is founded on a visual economy that is extractive. Indeed, in thinking about our positionality and relationality to photography, this recalibration of the surplus value of photography should force researchers as well to consider the possible extractive nature of their research especially when handling, dominating, hording or claiming ownership over photographs that are given value because their content emerges from some social relationship with the colonised; in this case, Palestine and the Palestinians. ${ }^{9}$

Ariella Azoulay reminds us that, for a Palestinian, 'going to Israeli archives is not an option, because under the imperial regime of the archive he was deprived of the archives that existed in Palestine. ${ }^{10}$ Indeed, the Israeli archive 'houses' - or perhaps, better, confines under its naturalised policy of indefinite administration detention - not only purloined documents, images and artifacts, but suppressed facts and narratives that evince their historical claims, their narratives and stories of Zionist violence and dispossession. ${ }^{11}$ Yet, still, the Israel archive is a contrived space predicated precisely on the control, management and erasure of Palestinians, collectively and individually. The Israeli archive is a place of dispossession and prohibition for the Palestinian, but also detainment and suppression. Coming up with strategies to resist and think through the histories delimited and demarcated by the settler society becomes even more complicated when we also remember that photography itself is deeply imbricated with colonialism and coloniality. That is, "[p]hotography was imperial from the very beginning', as Azoulay reminds us. The 'negation of people's right to actively participate in (let alone give consent to) being photographed is not part of the ontology of photography, but is the outcome of the extractive principle on which photography was first institutionalized.' ${ }^{12}$ When one reconsiders the place of the archive and the 'nature of photography' then we understand the importance of why Rana Barakat asks us to centre and amplify Palestinian stories, narratives, and objects of knowledge - not

$9 \quad$ For another example of the decolonial method that allows us to seize the image and relocate it within centered Palestinian-Arab existence, material realities, and histories, see "The Palestinian Spectator and Emancipating History" in Issam Nassar, Stephen Sheehi, and Salim Tamari, Camera Palestina: Photography and Displaced Histories of Palestine (Berkeley: University of California Press, forthcoming).

10 Ariella Azoulay, Potential History: Unlearning Imperialism (New York: Verso, 2019), 163.

11 I am referring to the research of Israel's New Historians, who could enter the state archives to access documents pertaining to the 1948 Nakba when they were declassified. The most noteworthy of these works is the Ilan Pappé, The Ethnic Cleansing of Palestine (London and New York: Oneworld, 2006). 
settler-colonial places, spaces, and narratives - as elemental to 'writing/ righting' the history of Palestine. ${ }^{13}$

When we think about photography in the context of colonialism, in particular, we realise how the social relations that mediate the relationships around photography are further convoluted by the relationship of colonised peoples to visual regimes, social configurations and political formations that themselves are embroiled with the introduction of racial capitalism, colonialism, and modernity. ${ }^{14}$ Photography then is always contaminated and a site of contention for the colonised to make claims. Photography is not only a locus of the production of meaning, but a locus for the production of knowledge for the colonised as much as the coloniser.

To be clear, when the right of photography, or the right to the truth-value of photography, is denied, when the right of the victim is denied by the victimiser, the weak have a right to emancipate the image, to tactically excavate 'truth-value.' The manifest of the image may, in fact, obfuscate this 'truth-value'. Therefore, the colonised may seek a method and practice to conjure indigenous knowledge through associations with other facts in order to represent the truth of the material conditions the image represents. This is the beginning of the decolonisation of photography. Methodologies of decolonisation do not dismiss the facticity of the photograph in a gesture towards radical relativism. In no way, do decolonial methodologies invent 'alternative facts', frequent among right-wing, ethno-nationalist, and fascist movements. Rather, they exorcise, in Alloula's words, the hegemony of colonial epistemology. They validate and centre the experiences, stories, knowledge and realities of indigenous people. They centre history and analysis on facts that have been displaced, shattered, buried (sometimes literally) and dismissed. Decolonial method understands that if truth is suppressed or pushed to the margins, it is because truth-value is mediated by power, force and conscription. Decolonial methodology, as Linda Tuhiwai Smith methodically shows us, truth is produced; truth is constructed through the production of knowledge, but also on the elevation of experience and affect; facts are discursive, collective and social products, while still being empirical. ${ }^{15}$ Facts are empirical and relational, standing tension, complimentary and in relation to other facts. It is not coincidental that Edward Said in

\footnotetext{
13 Rana Barakat, "Writing/Righting Palestine Studies: Settler Colonialism, Indigenous Sovereignty and Resisting the Ghost(s) of History," Settler Colonial Studies 8, no. 3 (2018): 349-363.

14 See Stephen Sheehi, "The Nahda After-Image, or All Photography Expresses Social Relations," Third Text 26, no. 4 (2012): 401-414.

15 Linda Tuhiwai Smith, Decolonizing Methodologies: Research and Indigenous Peoples (New York: Zed Books, 2013).
} 
Orientalism frequently looks to Giambattista Vico to unravel how discourses are produced through the constitution and arrangement of facts. ${ }^{16}$ Facts are related to empirical and material realities, realities that we create through social forces and power structures; realities constructed through the dialectics of the powerful and social formations, those who they attempt to control, co-opt, and/or resist-through a number ideological and material means knowledge production.

In this regard, I have argued elsewhere that photography is an example of Vico's verum factum. ${ }^{17}$ The means of knowledge production is in the hands of the powerful. In the form of the photograph, it can constitute a visual archive that determines the parameters by which we define all that is seen. ${ }^{18}$ Therefore, understanding the photograph as being a verum factum is not to say that just because we say something is true, it is true. But it is for us to wrestle control of the means of knowledge production by conjuring the latent and manifest content of photography, by connecting it to other facts, to material realities, in order to emancipate its meaning. Indeed, Katherine McKittrick entices us to believe the 'truthful lies' put forth by the archive that tell us of the violence until black people are born free. This impulse to 'trust the lies' is not to agree to their truth, but to produce a form of knowledge that serves to evince what black people know to be the facts; namely they are free despite all the social lies that perpetuates and naturalises violence against them. ${ }^{19}$

The correlation between the black experience in the United States and that of Palestinians in Palestine under Zionist hegemony should not be lost on us, despite the profound differences. Indeed, Saidiyah Hartman illustrates what I am alluding to when we think of seizing images, 'trusting the lie' in order to give witness to the facts. Hartman's handling of a number of photographs of anonymous black girls from the decades around the turn of the twentieth century tease out both the racial violence encoded in the images, but also lived experiences and social formations, indeed evidence of revolutionary and rebellious black lives, that escape the confines of a white supremist syntax of photographic representation. ${ }^{20}$

\footnotetext{
16 Edward Said, Orientalism (New York: Knopf, 1978).

17 For a theoretical development and demonstration of my theory of the verum factum of the photograph, see Chapter Four: "Writing Photography", in Sheehi, Arab Imago.

18 For a critique of the archive and photography's imperial and imperious relationship to it, see Azoulay, Potential History.

19 Katherine McKittrick, "Mathematics Black Life," The Black Scholar 44, no. 2 (2014): 21 and 20, respectively.

20 Saidiya Hartman, Wayward Lives, Beautiful Experiments: Intimate Histories of Social Upheaval (New York: Norton, 2019).
} 
Speaking more to the images at hand, we are confident that, while the Armenian photograph is a 'fake', the facts it communicates are true: the Armenians were exterminated by the Ottoman government through deprivation. Even if the murder of Muhammad Durrah was staged as the most heinous and cynical critics suggest, the image stands as absolute and unequivocal evidence for the cruel realities of an illegal and brutal occupation and its effects on Palestinian children and their families.

\section{What Is the Decolonisation of Photography}

The decolonisation of photography is not magical undoing. It is not an ahistorical process or a reading through nationalist frameworks that sees indigenous photography as 'speaking back' to power. In the Middle East, at least, decolonisation of photography should not seek an 'epistemic reconstruction', in the words of South American thinker Anibal Quijano. ${ }^{21}$ Conjuring pre-Oedipal fragments of selfhood or awaking dormant histories are not the same as hoping to resurrect arcane or dead practices, fetishising them as authentic culture.

The process of decolonisation should not be confused with a recovery of a lost, destroyed or displaced self. It is the acknowledgement of lost selfhoods that are only knowable through their displacements and uncanny fragments, which themselves come to us through the filter of selfhood that is our own, but also doubled subjectivity as W.E.B. De Bois, Frantz Fanon, Abdelkebir al-Khatibi have observed. But, this is not its sole end. Decolonisation is the fleshing out, remembering, conjuring and an accounting of the ways in which extraction took place, but also continues to unfold, often with the complicity and conscription of indigenous bourgeoisie, politicians, oligarchs, and social formations. It is this process of decolonisation, along subjective, gender and class lines that authenticates, produces and centres indigenous, but not parochial, knowledge and conscientiousness.

If colonial modernity is a system of knowledge-production not simply empirical reality, as Santiago Castro-Gomez suggests, it is unlinkable from a colonial/modern/capitalist matrix of Middle Eastern subjectivities, practices, (and their subaltern negatives) through which the necropolitics of the colony and postcolony are naturalised. ${ }^{22}$ Decolonisation therefore entails

21 Aníbal Quijano, "Coloniality and Modernity/Rationality," Cultural Studies 21, nos. 2-3 (2007): 176 .

22 Santiago Castro-Gómez, "The Missing Chapter of Empire: Postmodern Re-organization of Coloniality and Post-Fordist Capitalism," Cultural Studies 21, nos. 2-3 (2007): 428-48. 
then a seizure of means of knowledge production, among them photography, and thereby the seizure of the rights to photography and photographic representation. The seizure does not involve an adoption of an archive that lends credibility to a dominant, indigenous elite history of the Middle East; that is, using the photographic archive as evidence for the Middle East's belle époque, how women were liberated, how men were literate, went to the beach and drank whisky and loved democracy. The work of Fouad Debbas, Badr el-Hage, Michel Fani, for example, are a claim to nostalgia and absence, not a claim to the rights of looking or the claim to the rights of photography's truth value. ${ }^{23}$

For all their talk about discovering the 'lost heritage' of Middle East photography, the photograph, for them, is used to shore up nationalist and class nostalgia and displace the violence that operates within the latent content of the image. This nostalgic approach to photography creates the 'alt-history' or 'alt-heritage' and only instrumentalises photography as a means of justifying and naturalising one particular class world view and ideological hegemony.

I use the language of 'seizing' or appropriation because it allows us to be empowered, agile and militant with our methodology. In seizing photography, we seize 'expatriate, Orientalist, and state imagery' as readily as reaching to indigenous or 'vernacular' photography. Native photography itself is not understood as a resistance to imperialism or Orientalism, but is indicted in forms of power, class assertion and social formations. Therefore, it constitutes an object, indeed a site of contention, that itself needs to be seized, rehabilitated and repurposed. Decolonisation therefore entails a seizure of means of knowledge production, among them photography, and thereby the seizure of the rights to photography and photographic representation. The photograph is a social space, a collective process, a cultural and geographic articulation and a social object. As such, all are available for re-appropriation by the colonised in order to emancipate the subjects of the photograph, the verum factum and truth value of their experience, and the visibility of facts that are disavowed, permitting us as liberated subjects to create the opportunity for new social relations.

23 Fouad Debbas, Beirut: Our Memory; A Guided Tour Illustrated with Picture Postcards, and ed. (Beirut: Naufal, 1986); Michel Fani, Liban 1848-1914: L'atelier photographique de Ghazir (Paris: Éditions de l'Escalier, 1995); Khalidi, Before the Diaspora; and Badr el-Hage, Saudi Arabia: Caught in Time 1861-1939 (London: Garnet, 1997). 
Seizing the rights to photography demands a decolonial method that contains a number of different techniques of radical appropriation. It is an understanding of photography as a multivalent practice, that involves a number of indexical, empirical, ideological and representational fields that can be weaponised, converted into a plane of contention in order to seize the means of ideological, economic or knowledge production.

What I hope to offer is not a grand and new method, but an organising method. In many ways, this method dovetails with recent scholars in North America such as Ali Behdad, Jennifer Bajorek and Hanna Feldman to 'unmoor' or 'unfix' the image from the Orientalist lens, without necessarily understanding the collusion between Orientalist, colonialist and indigenous social formations. ${ }^{24}$ Likewise, Yazan Kopty, in this very volume, offers and practices a method by which images are repatriated and re-indigenised despite their extractive and exploitative origins with National Geographic. Furthermore, a broad naming, corralling and rerouting of techniques that reappropriate and reposition the colonial subject's relationality to the image has been practiced by scholars, photographers and artists in the postcolony for decades. Malek Alloula, for example, started this project when he announced a desire to 'force the postcard to reveal what it holds back (the ideology of colonialism) and to expose what is repressed in it (the sexual phantasm)'25 His ground-breaking book is explicitly referred to as an 'exorcism. ${ }^{26}$ Approaching the photograph as an image-screen, as verum factum, is one such technique. Transfiguring the photograph into a space to emancipate the colonised spectator within us (to riff on Rancière), who has been denied the rights of visibility, who has been denied to right to the truth value of photography. ${ }^{27}$ How then is decolonising photography to be done? Since the surface of the photograph as an image-screen is a locus of mediation of social relations (of power and resistance), Freud and his approach to dream-work provide us with one technique for this

24 See Jennifer Bajorek, Unfixed: Photography and Decolonial Imagination in West Africa (Durham, NC: Duke University Press, 2020); Ali Behdad, Camera Orientalis: Reflections on Photography of the Middle East (Chicago: University of Chicago Press, 2016); and Hanna Feldman, From a Nation Torn: Decolonizing Art and Representation in France, 1945-1962 (Durham, NC: Duke University Press, 2014).

25 Malek Alloula, The Colonial Harem (Minneapolis: University of Minnesota Press, 1985), 4.

26 Alloula, 5.

27 Jacques Rancière, Politics of Aesthetics: Distribution of the Sensible, translated by Gabriel Rockhill (London: Continuum, 2004). 
decolonising methodology, allowing us to seize the image-screen as a composite of manifest and the latent content of positive, negative and displaced images.

In the manifest, we explore the indexical, the representational, the compositional, the aesthetic qualities of the photograph, all which communicate particular meanings within a dominant discourse. The manifest is read through the dominant ideology (and reproduces it) within particular social and political contexts. We may extend Marx's formulations of the essential components of economic formations to photography, found in 'Introduction to a Critique of Political Economy', where visual, like economic formations, are based on a series: production, distribution, exchange and consumption, where 'every form of production creates its own legal relations, forms of government, etc.'. 28

The latent is, however, all that makes the manifest legible and that which the manifest may displace. It is the alterity of the image, the denied, the displaced and the repressed. One searches for the latent in a number of ways, and the latent is multitude, but that does not mean everything goes. Like Freud's method, one maps the manifest through its narration and its index, and the latent through a process of association, historical inquiry, representational genealogy, deep space of discourses that make manifest intelligible and exploring the image's effect and affect. ${ }^{29}$ To illustrate the method, I reach to an image that lays at the junction between the Genocide and the Occupation of Palestine, two issues bound by the denial of suffering and violence.

\section{Palestine in a Plate of Hummus}

Elia Kahvedjian (1910-1999) was born in Urfa and, by age five, was a refugee of the Armenian genocide. He lost five brothers, three sisters, mother, father, all uncles, aunts and grandparents, all save a sister who he found 18 years later. During the death march, his mother sold him to Kurds, where he was renamed 'Abdū and worked as a blacksmith's apprentice. When blacksmith's new wife didn't want him, Elia was 'thrown into the streets' and became a beggar, where, allegedly, he was almost kidnapped and murdered by cannibals in a tale right out of 1001 nights (given food, he was taken to cave, where he slipped and fell upon human skulls, as he escaped, the kidnapper threw a sword and injured

28 Karl Marx, "Introduction to a Critique of Political Economy," in The German Ideology (Amherst, NY: Prometheus, 1988), 5 .

29 Sigmund Freud, The Interpretation of Dreams. The Standard Edition of the Complete Psychological Works of Sigmund Freud, IV and v (190o); James Strachey, trans. and ed. (London: Hogarth Press, 1953). 
his leg where he carried a scar). By age 11, the American Near East Relief Foundation saved him along with thousands of Armenian orphans and relocated him to an orphanage in Nazareth, where he learned photography. He moved to Jerusalem and started to work for Hanania Brothers studio, eventually buying and renaming it 'Elia Photo Service.'30

Elia Photo Service was successful, partially due his relationship with the Jerusalem Order of Freemasons and its tight connections with British authorities, what his son, the current owner, referred to as 'help from above'. Elsewhere, his son states that Elia worked with the British Army and Air Force, developing and printing their pictures. ${ }^{31}$ This is likely considering the existence of a small number of Kahvedjian's aerial photographs. The common rumour that I found in my own conversations with Jerusalemites was that Kahvedjian was British 'spy'. Perhaps coincidentally, his son relates that in 1948, a British officer told Kahvedjian to gather his things on the eve of the Nakba and leave his store on Jaffa Street. ${ }^{32}$

Kahvedjian's photographs differ from that of the American Colony and Khalil Ra'ad. The former portrays Palestine as unaffected by British occupation and Zionist settlement. They idealise or exoticise Palestinians, largely naturalise British presence, and, to a lesser extent, document Zionist life in Palestine: images are, for example, of the wheat harvest, veiled women, fortune tellers, Domaris, coffee sellers, porters with blurred 'modern' men in background and sign which seems to be in Hebrew and Arabic; there are architectural photographs such as that of Damascus gate that diminish the presence of military offices whose blurry figures blend in with 'natives' in Arab garb. Images such as that of a shabby Jewish sous seller (clearly a member of the non-Ashkenazi Old Yishuv), the legendary Hurva Synagogue in Jewish Quarter, Dizengoff Square in Tel Aviv, a Purim parade, the entrance to Rosh Hanikra kibbutz, the Kapulsky coffee wagon (which would become an Israeli chain) and the Zeppelin over Jerusalem all are popular images among Israelis. ${ }^{33}$

30 This information was relayed first hand to me by Kevork Kahvedjian at Elia Photo in Jerusalem. Some of the biographical information can also be found in Kevork Kahvedjian, Jerusalem Through My Father's Eyes (Jerusalem: Elia Photo Service, 1998).

$31 \quad$ For an example, see "Aerial View of Jerusalem 1936," Kahvedjian, Jerusalem Through My Father's Eyes, 59 .

32 Allen Williams, "Dom Photographs in the Collection of Elia Kahvedjian," in Kuri:Journal of the Dom Research Center vol. 1, no. 10 (2004), found at http://www.domresearch center.com/journal/110/elian1o.html, last accessed Feb. 2, 2020; and Nir Hasson, "The Finest Photographs of Early 2oth Century Palestine, Shuttered in Controversy," Haaretz, Feb. 5, 2012, http://www.haaretz.com/print-edition/features/the-finest-photographs-of -early-2oth-century-palestine-shuttered-in-controversy-1.411086, last accessed Feb. 2, 2020. 
There are, however, among this collection a small handful of quotidian images, with movement and a documentary quality. One of the most popular photographs sold in Elia Photo Services is the image of men 'eating hummus' (1935). The image depicts workers in the winter in Jerusalem's Old City, eating hummus at an outdoor hummus kiosk. Indeed, the image can be read a number of ways. It is contemporary and even pushes back on many of the character types and idealised images of Kahvedjian's commercial practice.

On the one hand, what we can call the manifest level, the photograph can easily be romanticised, representing a space where the tribulations of Zionist colonisation and British rule in Palestine are absent. It can be seen as a sort of free-space of pure enjoyment, comradery and social interaction, which has yet to become saturated by the colonisation process or the vagaries of British rule.

The comments and analysis of the image, more often, concentrate on the centrality of hummus as a universal identification with these men, not as Palestinians, but as guys, like you, me and Israelis, who just cannot help but love hummus.

The impulse to displace the Palestinian experience, and indeed presence, in photography is captured in an interview precisely about this image by an Australian filmmaker, Trevor Graham. Graham started a blog, titled 'Make Hummus Not War'. In 2011 published an interview on his blog with Elia's son, Kevork Kahvedjian, who subsequently has passed away. Graham's project tracing Palestinian, Lebanese and Israeli competing claims to hummus eventually became a film by the same name. ${ }^{34}$ Graham asks Elia's son what he thinks about the 'hummus controversy' where Israelis claim the dish as their own. The studio owner replies, hummus 'is so delicious, that everybody tries to claim it for themselves. It's okay. As long as it's delicious, I don't care. I don't mind'. ${ }^{35}$ Kahvedjian clarifies his priorities, saying 'the situation here is hard for everyone, although I can tell you that the Armenians are positively neutral people. We are a family of photographers, and that's what interests us'. ${ }^{36}$

Kahvedjian's answer and the interviewer's questions - and certainly the commercial popularity of the trope of substituting hummus for contention employs a critical psychological defensive mechanism; that of disavowal.

34 Trevor Graham, Make Hummus Not War (Australia, 2012), 1:17 mins.

35 Trevor Graham's 2011 interview with Kevork Kahvedjian is reproduced on his blog, Make Hummus Not War, found at http://www.makehummusnotwar.com/characters_14.html, last accessed Feb. 2, 2020.

36 "Elia Photo Service in Jerusalem," ClaudiaExpat, June 2012, found at https://www .expatclic.com/elia-photo-service-in-jerusalem/?lang=en, last accessed Feb. 3, 2020. 


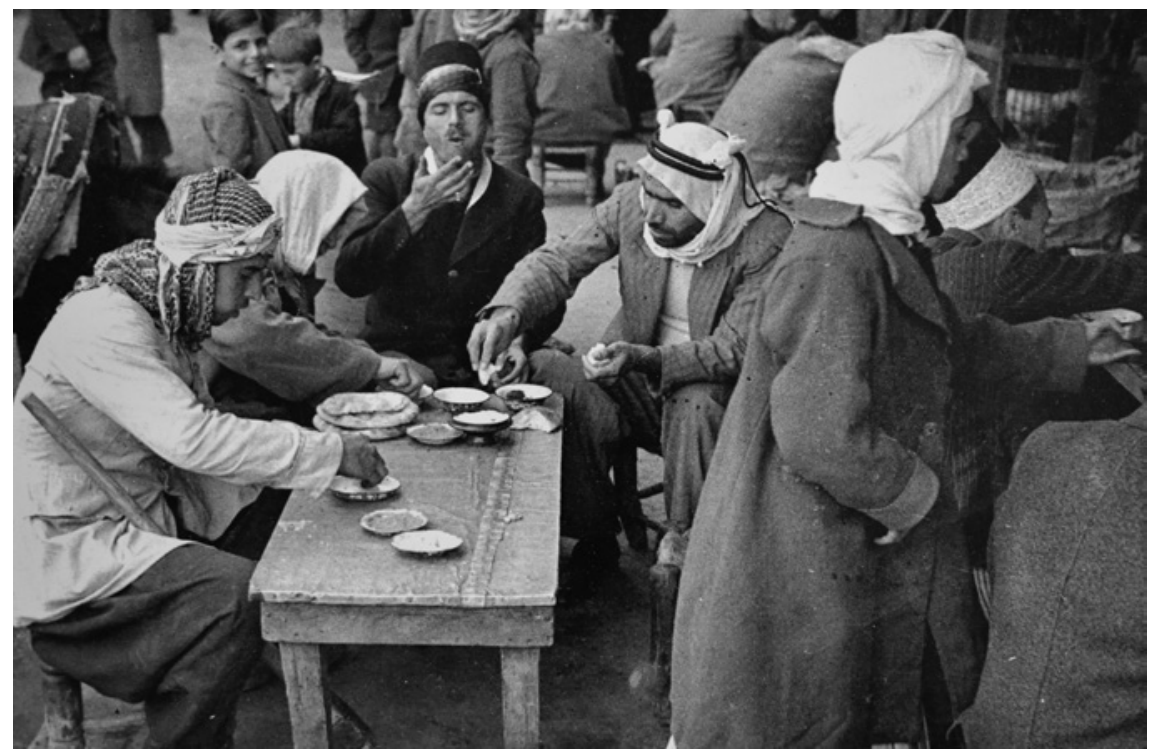

FIGURE 10.3 Eating Hummus, 1935. Elia Kahvedjian. Elia Studio Jerusalem

Disavowal (for Freud, or 'foreclosure' for Lacan - Verwerfung-forclusionrepudiation $)^{37}$ allows one to 'repudiate' discordant reality that threatens the self-image and ego-coherence. Disavowal splits off the part of reality from the self that causes dissonance and discomfort invoked by reality.

The obsession with hummus serves as a culinary universal that assumedly connects people and temporalities, but also it repudiates historical and social realities. Kahvedjian's disavowal of the historical and contemporary realities of Palestine protects the assumed 'neutrality' of the Armenian community within the Palestine-Israel conflict. It contains an annihilation anxiety passed down through the transgenerational transmission of the trauma of genocide and insisting the 'neutrality' of the Palestinian-Armenian community: let's ignore - that is, disavow - history. Let's repudiate the asymmetries of present realities. It's hard for everyone. Hummus is so delicious and photography is apolitical and what really 'interests us'.

But on a larger scale, the fixation of this indexical surface invokes a nostalgic identification with the act of simple eating, eating hummus en pleine air, on rustic tables, tin plates, with simple bread while the compactness of the image and the overflowing figures highlight the apolitical act of the universal

37 Jacques Lacan, The Seminar. Book III. The Psychoses, 1955-56, trans. Russell Grigg (New York: Norton, 1993). 
sociability of eating. Everybody loves hummus. It defends the coherence of liberal narratives that assert 'make hummus not war', which is the name of the blogger's site.

The reading of 'eating hummus' and the rapture of hummus deflects from and denies the political and historical realities and imperatives of $1930 \mathrm{os}$ Palestine. Indeed, we do not have to 'care' about the claim that hummus can be 'Israeli' without being Palestinian because it is 'so delicious'. The retreat into the shared commonalities of our humanity, coupled still with the anonymity of the photograph's subjects, converts the image into a validation of the hummus-loving spectator not the Palestinian as a national, political and class subject. The official title, in fact, is 'Eating Hummus': a title with no subject.

To arrive at the latent, we start at this manifest, the all-male space broken by the variety of ages, the smile of the boy in the background acknowledging the photographic event while, at the same time, the three men are lost in the ecstasy of extending their bread into their dishes and the central figure is almost performative in his hummus rapture. There is no sense of 'traditional men' doing 'traditional' work, both terms that can only be ambiguous and clarified with stereotyped answers and images. The photograph is, however, unambiguously an image of men who work; modern workers. It is an infrequent image of 'real' Palestinian labourers, very likely carbing up in the morning for their long day's work in a cold, damp Jerusalem winter.

This reading is the beginning of latent analysis, which should not be confused with speculation. The analysis of the latent allows us to identify and root analysis in material and historical realities (in and out of the frame) that saturates an image and burst through the orientalised, commodifying lens. This liberation of an image allows it to be read as document and/or enunciation of the quotidian life of modern Palestinian labour. But what is outside this image of workers and kept at bay by the fetishised delights of hummus? The labour in this image is likely an effect of the historical moment, labour that was essential to the economic transformations and jostling of the 193os. The origins of urban labour lay in the dispossession of Palestinian peasantry during the 1920 s and 1930s, who were removed from lands after they were sold by absentee landlords to the Jewish National Fund. Others were subject to increased rents and ravaged by two decades of over-taxation. Yet more were adversely affected by the transformation of the Palestinian economy with the opening of Palestine's market to cheaper imported goods by the British.

The disenfranchisement and increased landlessness of the Palestinian peasantry led to the migration of rural Palestinian communities to urban areas, at the same time that the British declared a minimum wage for Palestinians less 
than that minimum wage required for Jewish labour. ${ }^{38}$ As a result, the construction boom sparked by large scale Zionist construction projects and the Mandate government - a boom that contrasted the agricultural downturn - was often facilitated by cheap Palestinian labour until the Great Revolt of $1936 .{ }^{39} \mathrm{To}$ look at these labourers in 1935, we understand their origins and their material conditions. Moreover, we understand the history, the present and the direction of this image, not frozen in hummus rapture, but within their contemporary social relations that will make for a revolt.

These workers became the fighters of that popular uprising against Zionist colonisation and British rule. The Great Revolt of 1936-1939, in fact, started with a widespread and comprehensive national strike. The strike was largely organised and initiated by Palestinian labour, whose up-swell of pressure forced the Palestinian elite to sign on (and later usurp). Therefore, perhaps the more accurate title of this photograph should not be 'Eating Hummus, 1935' but 'Palestinians on the Eve of the Great Revolt'.

\section{Bibliography}

Alloula, Malek. The Colonial Harem. Minneapolis: University of Minnesota Press, 1985. Azoulay, Ariella Aisha. Potential History: Unlearning Imperialism. New York:Verso, 2019. Barakat, Rana. "The Jerusalem Fellah: Popular Politics in Mandate-Era Palestine." Journal of Palestine Studies VLVI, no. 1 (2016): 7-19.

$38 \quad$ Zachary Lockman clearly shows that the British worked to suppress the wages of Palestinian workers and peasantry and keep them always subordinate to and below mandated minimum wages for Jewish settlers. See Zachary Lockman, Comrades and Enemies: Arab and Jewish Workers in Palestine, 1906-1948 (Berkeley: University of California Press, 1997); for example, 101-102. For a recent and very thorough examination of the process by which Zionist 'development' caused Palestinian peasantry to become dispossessed, see Charles Anderson, "The British Mandate and the crisis of Palestinian Landlessness, 1929-1936", Middle Eastern Studies, 54, no. 2 (2018), 171-215.

39 For a more extension discussion of the Great Revolt, see Rana Barakat, "The Jerusalem Fellah: Popular Politics in Mandate-Era Palestine," Journal of Palestine Studies, vLvi, no. 1 (2016); Matthew Kraig Kelly, "The Revolt of 1936: A Revision," Journal of Palestine Studies, VLIV, no. 2 (2015): 28-42; Julie Peteet, Gender in Crisis:Women and the Palestinian Resistance Movement (New York: Columbia University Press, 1991), 33-66; Ellen Fleischmann, The Nation and Its "New" Women: The Palestinian Women's Movement 1920-1948 (Berkeley: University of California, 2003); and Ted Swedenburg, Memories of Revolt: The 1936-1939 Rebellion and the Palestinian National Past (Fayetteville: University of Arkansas, 2003). 
Barakat, Rana. "Writing/Righting Palestine Studies: Settler Colonialism, Indigenous Sovereignty and Resisting the Ghost(s) of History." Settler Colonial Studies 8, no. 3 (2018): 349-363.

Bloxham, Donald. The Great Game of Genocide: Imperialism, Nationalism, and the Destruction of the Ottoman Armenians. Oxford: Oxford University Press, 2005.

Castro-Gómez, Santiago. "The Missing Chapter of Empire: Postmodern Re-organization of Coloniality and Post-Fordist Capitalism." Cultural Studies 21, nos. 2-3 (2007): 428-448.

Dadrian, Vahakn. "The Armenian Question and the Wartime Fate of the Armenians as Documented by the Officials of the Ottoman Empire's World War I Allies: Germany and Austria-Hungary." International Journal of Middle East Studies 34, no. 1 (2002): $59-85$.

Debbas, Fouad. Beirut: Our Memory; A Guided Tour Illustrated with Picture Postcards. 2nd ed. Beirut: Naufal, 1986.

El-Hage, Badr. Saudi Arabia: Caught in Time 1861-1939. London: Garnet, 1997.

El-Hage, Badr. Shweir and Its Hills: A Photographic Record. Translated by Sabah Ghandour. Beirut: Kutub, 2013.

"Elia Photo Service in Jerusalem." ClaudiaExpat, June 2012. Found at https://www .expatclic.com/elia-photo-service-in-jerusalem/?lang=en. Last accessed Feb. 3, 2020.

Elmessiri, Abdelwahab. The Palestinian Wedding:A Bilingual Anthology of Contemporary Palestinian Poetry. Washington, D.C.: Three Continents Press, 1982.

Fani, Michel. Liban 1848-1914: L'atelier photographique de Ghazir. Paris: Éditions de l'Escalier, 1995 .

Fleischmann, Ellen. The Nation and Its "New" Women: The Palestinian Women's Movement 1920-1948. Berkeley: University of California, 2003.

Graham, Trevor. Make Hummus Not War (Australia, 2012). Film and blog. Trevor Graham's 2011 interview with Kevork Kahvedjian is reproduced on his blog, found at http://www.makehummusnotwar.com/characters_14.html. Last accessed Feb. 2, 2020.

Hartman, Saidiya. Wayward Lives, Beautiful Experiments: Intimate Histories of Social Upheaval. New York: Norton, 2019.

Hasson, Nir. "The Finest Photographs of Early 2oth Century Palestine, Shuttered in Controversy." Haaretz, Feb. 5, 2012. http://www.haaretz.com/print-edition/features/ the-finest-photographs-of-early-2oth-century-palestine-shuttered-in-controversy -1.411086. Last accessed Feb. 2, 2020.

Kelly, Matthew Kraig. “The Revolt of 1936: A Revision.” Journal of Palestine Studies VLIV, no. 2 (2015): 28-42.

Khalidi, Walid. Before Their Diaspora: A Photographic History of the Palestinians 18761948. Washington D.C.: Institute for Palestine Studies, 1984. 
Lacan, Jacques. The Seminar Book I: Freud's Papers on Technique 1953-54. Translated by John Forrester. New York: Norton, 1988.

Lacan, Jacques. The Seminar. Book III. The Psychoses, 1955-56. Translated by Russell Grigg. New York: Norton, 1993.

Marx, Karl. "Introduction to a Critique of Political Economy." In The German Ideology. Amherst, NY: Prometheus, 1988.

McKittrick, Katherine. "Mathematics Black Life." The Black Scholar 44, no. 2 (2014): 16-28.

Mirzoeff, Nicholas. The Right to Look: A Counterhistory of Visuality. Durham, NC: Duke University Press, 2011.

Kahvedjian, Kevork.Jerusalem Through My Father's Eyes. Jerusalem: Elia Photo Service, 1998.

Pappé, Ilan. The Ethnic Cleansing of Palestine. London and New York: Oneworld, 2006.

Peteet, Julie. Gender in Crisis: Women and the Palestinian Resistance Movement. New York: Columbia University Press, 1991.

Phillips, Melanie. "Faking a Killing." Standpoint, June 27, 2008. Found at https://stand pointmag.co.uk/faking-a-killing-july/?page $=0 \%{ }_{2} \mathrm{Co} \%{ }_{2} \mathrm{Co} \%{ }_{2} \mathrm{Co} \%{ }_{2} \mathrm{Co} \%{ }_{2} \mathrm{Co} \%{ }_{2} \mathrm{Co}$ $\% 2 \mathrm{Co} \% 2 \mathrm{Co} \%{ }_{2} \mathrm{Co} \% 2 \mathrm{C} 2$.

Qassim, Samih. "Kafr Qassim.” (Poem in Arabic).

Quijano, Aníbal. "Coloniality and Modernity/Rationality." Cultural Studies 21, nos. 2-3 (2007): 168-178.

Shaheen, Naseeb. A Pictorial History of Ramallah. Beirut: Arab Institute for Research and Publishing, 1992.

Sheehi, Stephen. "The Nahda After-Image, or All Photography Expresses Social Relations." Third Text 26, no. 4 (July 2012): 401-414.

Sheehi, Stephen. Arab Imago: A Social History of Portrait Photography, 1860-1910. Princeton: University of Princeton Press, 2016.

Swedenburg, Ted. Memories of Revolt: The 1936-1939 Rebellion and the Palestinian National Past. Fayetteville: University of Arkansas, 2003.

Williams, Allen. "Dom Photographs in the Collection of Elia Kahvedjian." in Kuri: Journal of the Dom Research Center 1, no. 10 (2004). Found at http://www.dom researchcenter.com/journal/110/eliano.html. Last accessed Feb. 2, 2020. 